\title{
FORGIVENESS AND THE SIGNIFICANCE OF WRONGS
}

\author{
Stefan Riedener
}

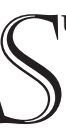
UPPOSE THAT, since a recent thunderbolt, the oak by Lila's house is frail. Hearing of an upcoming storm, she asks her neighbor Jack if he could help her cut it. She tells him that the tree is a hazard, that one cannot fell it alone, and that she will hire a saw in a distant city for the logging. Jack promises to be there to help. However, though he knows he is forgetful, he does not take measures to remind himself. And when the day comes, he fails to think of his promise, is nowhere to be found, and Lila has to return that saw without having cut a branch. What would it mean for Lila to forgive Jack for his promise breaking? A number of different accounts have been proposed. ${ }^{1}$ But a common idea is that Lila forgives Jack if she first feels a negative reactive attitude toward him for having broken his promise, and then overcomes this attitude in a certain way. ${ }^{2} \mathrm{I}$ will call this the standard account of forgiveness.

I think this account is promising. But it raises a number of questions. A first range of questions concerns the nature of forgiveness - or how exactly Lila must overcome her negative attitudes in forgiving. If she tricked herself into believing that Jack was not blameworthy in the first place, and therefore no longer has any negative attitudes toward him, she has not really forgiven. So there is a question about when an overcoming of such attitudes amounts to forgiveness. ${ }^{3}$ A second range of questions concerns the norms of forgiveness-or when exactly Lila is

1 For instance, some people hold that forgiveness is the exercise of a normative power (e.g., Warmke, "The Normative Significance of Forgiveness"; and Bennett, "The Alteration Thesis"), or the deliberate refusal to punish (e.g., Zaibert, "The Paradox of Forgiveness"), or a plurality of things with no clearly delineable essence (e.g., Neblett, "Forgiveness and Ideals").

2 The (contested) locus classicus of this is Butler, Fifteen Sermons. See also, e.g., Murphy and Hampton, Forgiveness and Mercy; Richards, "Forgiveness"; Holmgren, "Forgiveness and the Intrinsic Value of Persons"; Hughes, "What Is Involved in Forgiving?"; and Darwall, The Second-Person Standpoint, 72 (to name just a few authors in this tradition).

3 For a particularly clear statement of this problem, see, e.g., Hieronymi, "Articulating an Uncompromising Forgiveness." 
warranted to forgive, or perhaps would not be warranted not to. If the oak destroyed her house in that storm and yet Jack never showed any remorse, it would seem problematically condoning for Lila to forgive him straight away. ${ }^{4}$ On the other hand, if Jack has honestly apologized, organized the logging himself, and become a model of trustworthiness in the twenty-five years since then, it would seem problematically unforgiving for Lila to still bear her grudge. ${ }^{5}$ So there is a question about when the relevant overcoming of such attitudes is warranted. And these two questions are related. We can only really say when forgiveness is warranted once we know what it is. And we can determine what forgiveness is by reflecting on how overcoming such attitudes can be warranted.

My aim in this paper is to begin to answer these questions about the standard account. There are many proposals about how to do so. But my sense is that they often cannot explain how forgiveness may be warranted, or do so in a manner that distorts what it is. To illustrate what I mean, I will outline the challenge of accounting for the norms of forgiveness in section 1. In section 2, I will introduce one of the most prominent versions of the standard account, due to Lucy Allais. ${ }^{6}$ If my arguments are sound, her account of why forgiveness can be warranted is dubious, and her picture of its nature both too narrow and too broad. But Allais will provide us with an important insight. So I will then introduce a novel version of the standard account by elaborating on what I take from her. My core idea is that the reactive attitudes are fundamentally agent relative. They are a fitting response not just to someone's blameworthiness, but to their blameworthiness being significant for you, or worthy of your caring, in virtue of your relationship to it. Someone's blameworthiness is significant for you to the extent that you are bound up with what grounds it—e.g., with the wrongdoer's being a participant in human relationships, or the victim's being a source of demands. Thus you may fittingly not care about someone's blameworthiness if it is sufficiently insignificant for you-e.g., if they lived in a distant time and place. And forgiveness revolves around this. Lila (fittingly) forgives Jack for his fault if and only if, partly out of goodwill toward him, she (fittingly) does not care about his blameworthiness anymore. To explain and support these ideas, I will elaborate in sections 3,4 , and 5 on the reactive attitudes in general. In section 6 , I will relate this to forgiveness, and outline the proposal I have just sketched.

Two clarifications before I begin. First, I will focus on resentment as the paradigm attitude at stake. Actually, I think other attitudes-e.g., forms of disap-

4 For a forceful defense of this, see, e.g., Anderson, "When Justice and Forgiveness Come Apart.”

5 See, e.g., Watson, "Standing in Judgment."

6 Allais, "Wiping the Slate Clean." 
pointment or contempt-may also play a role in forgiveness. ${ }^{7}$ And I think the story I will tell about resentment could be applied to these attitudes too. But for simplicity, I will focus just on resentment. Second, I will focus on overcoming as the paradigm process at issue. Some people hold that, in order to forgive, rather than overcoming your resentment in the right manner, you need to forswear it, or endorse your lack of resentment no matter why you do not feel it. ${ }^{8}$ I think there is an important sense in which you have not forgiven me if you have forsworn but not yet overcome your resentment, and forgiven me if you have overcome your resentment (in the right manner) but have not forsworn it, and similarly, an important sense in which you have not forgiven me if you actually do not resent me out of sheer contempt but endorse that lack of resentment for the right reasons, and forgiven me if you have overcome your resentment (in the right manner) but do not yet endorse your lack of it. But not too much hinges on this. The alternative versions of the account face similar questions, about whether any forswearing or endorsing amount to forgiveness and when such stances are warranted. So much of what I will say could be employed for these alternative accounts as well. But I will focus on overcoming.

\section{THE PROBLEM}

Let us start with the question about the norms of forgiveness. Suppose that, in breaking his promise, Jack responsibly evinced a wrongful attitude toward Lila. She has the standing to blame him for it-e.g., is not notoriously unreliable herself. And she knows this. If this was not so, it would in different ways be problematic for Lila to feel resentment in the first place. But, given these assumptions, there is a question about how she may be warranted in overcoming it. Resentment is an emotion, so the precise nature of the question will depend on the nature and norms of emotions. There is a large debate about this, which I cannot enter here. But here are three standard assumptions that I will accept for this paper. First, emotions have standards of "fittingness." A certain fear of a dangerous snake is fitting-whereas fear of a totally harmless mouse, or excessive panic about a marginally dangerous dog, or a naively mild respect vis-à-

7 On disappointment, see, e.g., Richards, "Forgiveness," 78; Smith, "Moral Blame and Moral Protest," 38; Blustein, Forgiveness and Remembrance; and Fricker, "What's the Point of Blame?” 172. On contempt, see, e.g., Pettigrove, Forgiveness and Love, 29.

8 On forswearing, see, e.g., Strawson, "Freedom and Resentment," 6; and Fricker, "Forgiveness." On endorsing, see Schönherr, "When Forgiveness Comes Easy." I will come back to one issue that Schönherr raises in note 48. Still other formulations include "forbearing or withdrawing" (Darwall, The Second-Person Standpoint, 72) or "letting go of" (Griswold, Forgiveness, 40) resentment. 
vis an extremely dangerous moose, are not. Second, emotions have fittingness conditions in virtue of being representational: (intense/mild) fear represents its object as (very/moderately) dangerous, and is fitting if and only if this representation is correct. So if some proposition $p$ is among the fittingness conditions of an emotion, that is because $p$ is part of this emotion's representational content. ${ }^{9}$ Third, fittingness is normative. That is, if the representational content of some emotion is $p$, then $p$ is a reason for you to have that emotion, and not- $p$ is a reason for you not to have it. ${ }^{10}$ We might say it is a "fittingness reason" (not) to have the relevant emotion.

These assumptions are rough. There is a question, say, about the precise nature of emotional representation. Perhaps to have an emotion is to make a sort of judgment, or to (quasi-)perceive the world as being a certain way, or to have an intentional feeling toward it. ${ }^{11}$ There is also a question about why fittingness matters. Perhaps it is simply constitutive of our adopting specific emotions that we take their fittingness to provide reasons. ${ }^{12}$ Or perhaps there are (in addition) bridge principles linking fittingness to other sources of normativity: perhaps you have a moral reason to have fitting emotions about instantiations of moral value properties (like moral wrongness, unfairness, or blameworthiness), or it is part of the good life to generally have fitting emotions, or objectively good..$^{13}$ And there is a question about whether there are other reasons for emotions - "non-fittingness reasons," or reasons of the "wrong kind." Suppose someone offers Lila $\$ 1,000$ if, or tortures a cat unless, she resents Jack for his promise breaking. Perhaps this gives her a non-fittingness reason to resent him. ${ }^{14}$ Or perhaps it does not give her a reason to resent him, but only a reason to want to resent him, or to take actions to bring it about that she will. ${ }^{15}$ These questions

9 For such an account of fittingness, see, e.g., D’Arms and Jacobson, “The Moralistic Fallacy”; Tappolet, "Values and Emotions"; and Rosen, "The Alethic Conception of Moral Responsibility." For a dissenting voice on the idea that emotions are representational, see, e.g., Hutto, "Truly Enactive Emotion"; also Deonna and Teroni, "Emotions as Attitudes." For a survey of different accounts of fittingness, see Howard, "Fittingness."

10 See Howard, "Fittingness," 3; for a dissenting voice, see, e.g., Maguire, “There Are No Reasons for Affective Attitudes."

On emotions as judgments, see, e.g., Nussbaum, Upheavals of Thought; and Solomon, "Emotions and Choice." On quasi-perceptions of the world, see, e.g., Prinz, Gut Reactions; and Tappolet, Emotions, Values, and Agency. On intentional feeling, see, e.g., Goldie, The Emotions. See, e.g., Sharadin, "Reasons Wrong and Right." For a theory along the lines of the final idea, see, e.g., Hurka, Virtue, Vice, and Value, ch. 1. See, e.g., Rabinowicz and Rønnow-Rasmussen, "The Strike of the Demon." See, e.g., Kelly, "The Rationality of Belief and Some Other Propositional Attitudes”; Parfit, 
need not concern us. In what follows, I will only be concerned with fittingness reasons, without specifying the way in which emotions are representational, or why correct representation matters. ${ }^{16}$ For even these rough standard assumptions raise a puzzle about forgiveness.

What is the representational content of resentment? A common answer seems to be that if you feel resentment toward me for an action, you represent me as thereby having manifested an attitude toward you that was morally wrong and for which I was responsible; and the stronger your resentment, the more seriously wrong you represent my attitude as having been, or the more fully responsible you represent me as having been for it. ${ }^{17}$ So on this understanding, you can misrepresent the facts by feeling resentment where there was no fault (or responsible wrong) at all, or by feeling an excessively strong form in the face of what was (in terms of wrongness and responsibility) a relatively harmless fault, or a trivializingly mild annoyance in the face of what was (in these terms) an outrageous one. But this raises a problem. It suggests that in feeling less and less resentment toward Jack or eventually overcoming it altogether, Lila would represent his attitudes as less seriously wrong or him as less fully responsibleor eventually as not being at fault at all. After all, on the present understanding, these are the only dimensions along which the content of resentment can vary. Yet Jack was at fault. So, on these assumptions, Lila's overcoming resentment seems to render her emotions unfitting. But we want an account on which Lila can forgive Jack fittingly, or without suggesting he was not at fault.

But perhaps that is too quick. We might try to resolve this by considering what it means that an emotion is fitting. If emotions have fittingness conditions in virtue of being representational, then that an emotion is fitting does not mean you must feel it in order not to misrepresent the facts. Suppose Angeline does not know of Jack's promise breaking in the first place, and therefore does not feel any indignation about it. Then she does not misrepresent Jack's fault. She just does not represent it at all. Similarly, Lila need not come to misrepresent Jack's fault

On What Matters, ch. 2 and app. A; and Way, "Transmission and the Wrong Kind of Reason." For a helpful survey of the discussion about "right kinds of reasons," see Gertken and Kiesewetter, "The Right and the Wrong Kind of Reasons."

16 For what it is worth, I find it plausible that there are no wrong kinds of reasons for feeling an emotion. And I find all of the suggestions about why fittingness matters plausible. The idea that it is morally good to have or problematic to lack fitting emotions about moral value facts, in particular, can explain why forgiving too readily or not readily enough might itself be morally blameworthy - a form of being condoning or unforgiving that is morally objectionable. This is suggested, e.g., by Strawson, "Freedom and Resentment," 23. In Strawson's framework I am "responsible" for an attitude roughly just if it is mine (and I am a normal adult). I do not mean to suggest anything else with talk of "responsibility" throughout this paper. 
in overcoming her resentment, but may just come to not represent it at all. And that is what she would do in forgiving, or so one might hold. But as an account of forgiveness, this is not convincing either. To begin with, it seems false that if Lila has forgiven she will lack any emotions about Jack's fault. In coming to forgive, she will typically feel various (continuously weaker) forms of resentment. And once she has forgiven, she might still feel sad that he wronged her, or be positively at peace with his fault, or even be grateful if it rendered her stronger. Indeed, it is unclear whether Lila can avoid any emotional representation of it. There is a difference between having no attitude toward something-e.g., simply not knowing about it - and feeling indifferent about it or reconciled with it. And at least as long as she knows of Jack's fault, it seems she must have some attitude or other toward it, be it insouciance, propitiation, acquiescence, or whatever. But in any case, most importantly, even if we could somehow describe her as not representing Jack's fault, this would not give us the picture we want. On the present assumptions, resentment would still be the one fitting response to Jack's negligence. So Lila could come to have an emotional state that is not unfitting, at best. But she would do so by failing to have the fitting response. She would manage to forgive only through a sort of emotional forgetting. Yet we arguably want an account on which Lila can have the (or at least $a$ ) positive fitting response to the fact that Jack wronged her.

We could also try to resolve our problem with a more complex account of resentment. For instance, we might suggest that if you feel resentment toward me for an action, you represent me as thereby having manifested an attitude toward you that was wrong and for which I was responsible and for which I still have not felt any remorse. This would explain how Lila may fittingly overcome her resentment, at least once Jack has felt remorse. It would raise the substantive question of whether remorse really is necessary for forgiveness. Personally I think it is not, and that Lila may sometimes forgive Jack even if he has not properly repented. But set this aside for the moment. ${ }^{18}$ The present idea has a more fundamental problem. It implies that once Jack has felt remorse, any further resentment would be unfitting. More generally, it now seems that once it is fitting for Lila to no longer resent Jack, it would eo ipso be unfitting for her to still resent him. But this too is unfortunate. It seems that Lila could, sometimes, fittingly not feel resentment

18 Kolnai, "Forgiveness." For the view that remorse or a "change of heart" is crucial, or that "unconditional forgiveness" is inappropriate, see, e.g., Novitz, "Forgiveness and Self-Respect," esp. 314; Griswold, Forgiveness, esp. 121-22; Couto, "Reactive Attitudes, Forgiveness, and the Second-Person Standpoint"; and Milam, "Reasons to Forgive." For the view that it need not be, see, e.g., Calhoun, "Changing One's Heart"; Holmgren, "Forgiveness and the Intrinsic Value of Persons"; Garrard and McNaughton, "In Defence of Unconditional Forgiveness"; Ware, "Forgiveness and Respect for Persons"; and Fricker, "Forgiveness." 
even when she could also fittingly feel it. That is why forgiveness can be a "gift": it is not something she must always either offer or refuse in order to respond fittingly to Jack's fault. So we want an account on which Lila can have discretion in fitting forgiveness - on which she can, at least sometimes, fittingly forgive Jack but also fittingly refrain from forgiving. ${ }^{19}$

In sum, there is a question about why to overcome resentment is not to misrepresent the facts, or to simply omit any representation of them, or the only way to represent them correctly. How can we sometimes fittingly overcome our resentment without taking refuge to emotional forgetting and without it being unfitting to continue to feel it? Forgiveness seems either unwarranted or required or at best an emotional void. Echoing Aurel Kolnai, we might call this the (apparent) "paradoxy of forgiveness."

\section{ALLAIS'S PROPOSAL}

Before I attempt to solve this problem, let us consider one of the most prominent developments of the standard account of forgiveness, due to Lucy Allais. ${ }^{21}$ If I am right, Allais's proposal is not successful. But it can teach us important lessons. So it will help us to start here. The core of Allais's account is a conception of what it is to blame someone. We generally have beliefs about other people's characters. But Allais suggests that we also have a way of "feeling about" or "affectively seeing" them as people. ${ }^{22}$ This is not so much a matter of our beliefs, but of the emotions we are disposed to feel toward them, the expectations with which we encounter them, the patterns of attention with which we see them, and so on. Allais calls this our "affective attitude" toward a person. And she holds that Lila blames Jack for his promise breaking if she lets it influence her affective attitude toward him. In doing so she "affectively sees" this fault as "centrally attaching to

A related idea is sometimes expressed by saying that forgiveness is "elective"; see, e.g., Allais, "Elective Forgiveness." However, Allais means by this that the wrongdoer cannot, or "paradigmatically" does not (642), have a moral claim to being forgiven. Again, my claim above is (at least in the first instance) about fittingness rather than moral obligations; and I am only claiming that we can sometimes fittingly forgive but also fittingly refrain from it-not that that is always so. For objections to Allais's stronger claim, see, e.g., Milam, "Against Elective Forgiveness."

Kolnai highlighted the rough problem that "forgiveness is either unjustified or pointless" ("Forgiveness," 99). Yet my problem is somewhat different from Kolnai's. I am concerned with the fittingness of emotions. Kolnai is not. As far as I can see, no one has stated the problem in precisely the manner I have.

Allais, "Wiping the Slate Clean." See also Allais, "Elective Forgiveness."

Allais, "Wiping the Slate Clean," e.g., 51. 
[his] character," and thus "holds it against him."23 Correspondingly, Lila forgives Jack for his promise breaking if, without coming to believe that he was not culpable for it, she ceases to let it influence her affective attitude toward him. In doing so, she ceases to affectively regard it as attaching to his character, and thus "wipes the slate clean" with respect to this fault. ${ }^{24}$

Allais provides an elaborate story about why this may be fitting. It relies on two claims. The first is skepticism about character judgments. Allais argues that we are "never perfectly positioned to judge people's characters," that such judgments are "always underdetermined by the evidence"-and specifically, that they are never "epistemically mandate[d]" by a person's responsible wrongdoing. ${ }^{25}$ In other words, even if Lila knows that Jack is culpable for his promise breaking, she will not have conclusive evidence about whether it expresses his character. The second claim is a view about fittingness. According to Allais, that an attitude is fitting does not mean that it is "epistemically mandated" by your evidence-but rather, that it is "epistemically permissible" or "not contradicted" by it. ${ }^{26}$ And within the range of what is not contradicted by your evidence, she suggests, your attitude may permissibly be a matter of what you "pay attention to." ${ }^{27}$ In other words, an affective attitude toward Jack is fitting so long as it is not contradicted by conclusive evidence about his character. His promise breaking neither provides conclusive evidence that it centrally attaches to his character nor that it does not. So Lila may fittingly come to adopt an affective attitude toward Jack that is not influenced by his promise breaking, and thus forgive him. But she may also fittingly (continue to) have an affective attitude toward him that is influenced by it, or refrain from forgiving.

What is appealing about this is that Allais separates the belief in blameworthiness from the actual attitude of blame. According to Allais, there are different criteria for when we must believe someone is blameworthy and when we must actually blame them in order to have correct beliefs and fitting emotions: we can fittingly refrain from blaming the blameworthy. In this sense, blameworthiness does not eo ipso "mandate" blame, and blame is more than an emotional registering just of someone's blameworthiness. I think this is right, and relevant for forgiveness.

But Allais's way of explaining it is not fully convincing. Most fundamentally, her picture of attitudes is dubious. It is not true that an attitude is (subjectively) fitting as long as there is no conclusive evidence against it. Suppose Theodore

23 Allais, "Wiping the Slate Clean," e.g., 51.

24 Allais, "Wiping the Slate Clean," e.g., 51.

25 Allais, "Wiping the Slate Clean," 60.

26 Allais, "Wiping the Slate Clean," 62, 60.

27 Allais, "Wiping the Slate Clean," 61. 
and Luke tell Lila how they judge Glory. Theodore reports that Glory once kindly helped him, and that he generally knows her as generous and kind hearted. Luke says she once strangely refused him a favor, and that he generally finds her ill-natured and mean. Suppose Lila regards them as equally reliable, has no other evidence, and tries to form a fitting attitude toward Glory. Allais suggests that she could now choose what to "pay attention to"-and may fittingly disregard Theodore's positive opinion and be outright critical about Glory, or vice versa. But this seems wrong. ${ }^{28}$ Lila's attitude is only (subjectively) fitting if it reflects her epistemic situation: if to some extent she withholds attitude, or perhaps tentatively regards Glory as being multifaceted. Inconclusive evidence makes certain specific stances (subjectively) fitting. It itself does not give us any discretion. So similarly, if Lila has insufficient evidence about whether Jack's promise breaking reflects his character, her attitude toward him is only fitting if it reflects this: if she withholds attitude, or perhaps regards him as capricious. Her lack of evidence per se does not make it fitting for her to ignore our incident outright. If Lila has discretion in fitting forgiveness, it must be grounded in the facts, or in the positive evidence she possesses.

Also, the relevant facts do not seem to be just whether Jack's fault is characteristic. It is an unduly narrow picture on which blame is all about character assessment. Of course, we sometimes have insufficient evidence about whether a wrong expresses someone's character. But at least on an ordinary understanding of "character," and ordinary standards of evidence, our evidence is often sufficient. And in some such cases we still have discretion in forgiveness. Lila might know that Jack's promise breaking is characteristic-e.g., expressive of his general insensitivity to the commitments he has entered. But perhaps nothing much happened as a result of his fault. And perhaps Lila managed not to depend on Jack any further, to just enjoy his endearing cheerfulness in brief encounters, his childlike absorption in the moment, or the oblivious kindheartedness with which he often does her a favor-and thus to see his whole unreliability with enough distance to simply not bother about it anymore. In that case, she might arguably fittingly cease to resent this entire character trait of Jack's. Or again, she might know that our promise breaking is not characteristic-e.g., if our incident lies in the past, and Jack has genuinely felt remorse and truly managed to become reliable. But perhaps that windstorm unrooted the oak so that it destroyed Lila's nineteenth-century family house. And perhaps Lila cut off all further interactions with him afterward - and never got over the fact that due to the muddler he was she has lost that treasured place. And in that case, she might fittingly continue to feel a certain grudge about that promise breaking. These 28 A related point is made by Ware, "Forgiveness and Respect for Persons," 253. 
responses would not simply be unfitting, or mistaken, as resentment would be if Jack had not been at fault in the first place. Blame and forgiveness are not all about character assessment. They are much more complex responses, it seems.

In another respect, however, Allais's account of forgiveness seems too broad. She does not say how Lila must come to a changed attitude toward Jack. But some ways of wiping the slate clean do not amount to forgiveness. Suppose Lila saw it as detrimental to her well-being that she is holding his fault against Jack. And suppose she therefore banged her head on the table until the blows severed the associative ties she drew between him and the incident, and it no longer affected her attitude toward him. Or suppose that Lila's mother died on the evening after the promise breaking, and her associative ties between Jack's promise breaking and the death of her mother are so strong that she somehow never holds it against Jack-just because whenever the incident comes up, the question of how to evaluate her neighbor dwindles into oblivion. In these cases, it seems, she has not properly forgiven. Not all ways of ceasing to affectively regard Jack's fault as attaching to his character are forms of forgiveness. ${ }^{29}$

Suppose all of this is right. Then our discretion in fitting forgiveness is grounded in the positive facts, not in our epistemic limitations. There is a complex variety of grounds for blame and forgiveness beyond character assessment. And yet not any way of wiping the slate clean amounts to forgiving. We must look for an alternative solution to our problem. So let us now turn to the account I propose. $^{30}$

\section{THE CORE IDEA: THE SIGNIFICANCE OF A WRONG}

My proposal will build on Allais's idea that we can fittingly refrain from blaming people even if they are blameworthy. But I will account for it differently. My core

29 Interestingly, Allais discusses the fact that some forms of overcoming negative reactive emotions do not amount to forgiveness (e.g., "Wiping the Slate Clean," 43-50, 57-58). She cites "forgetting the wrong," "putting the wrongdoer out of your mind," or "regarding her as beneath your concern" as examples (58). According to Allais, these things do not amount to forgiveness because they do not involve "a change in your [affective] view of the wrongdoer" (58) with respect to their wrong: they just mean you lack any such affective attitude toward them. My point is that even Allaisian changes in your affective view of the wrongdoer need not amount to forgiveness. This is because Allais does not add any constraints about how you must come to cease to affectively regard a fault as attaching to the character of your wrongdoer in order to forgive.

30 For some alternative proposals (differing from Allais's and mine), see, e.g., Kolnai, "Forgiveness"; Murphy and Hampton, Forgiveness and Mercy; Hieronymi, "Articulating an Uncompromising Forgiveness"; Calhoun, "Changing One's Heart"; Callard, "The Reason to Be Angry Forever”; or Na'aman, “The Fitting Resolution of Anger." 
suggestion will be that the representational content of resentment is more complex than the common assumption has it. The reactive attitudes are a response to someone's (putatively) responsibly evincing wrongful attitudes. But they are not just a response to that. This can be argued without reference to forgiveness. So in this and the following two sections I will set forgiveness aside and sketch a picture of the reactive attitudes that is independently plausible. ${ }^{31}$ I will come back to forgiveness in section 6 .

It is worth bringing to mind some commonplace facts. A myriad of people have at some point somewhere responsibly evinced wrongful attitudes, and we often know of that and respond to it emotionally. Yet we generally do not adopt proportionally strong reactive attitudes toward all of these faults. Suppose Lila knew that Emperor Hadrian was wittingly betrayed by his friend and predecessor Trajan in second-century Rome. And suppose she also knew that her husband, Robert, was wittingly betrayed by his friend Marcelle in precisely the same manner. Suppose she responds with some mild indignation to the first case, but with quite strong indignation to the second. This would be entirely natural. We would say that she cares more about Marcelle's fault than about Trajan's. Indeed, intuitively, such unequal caring seems warranted, or supported by reasons. Generally, there are reasons for you to care more or less about facts. The fact that Marcelle harmed her husband is a reason for Lila to care about her fault. But the fact that Trajan lived in ancient Rome, or was five feet, eight inches tall, or perhaps had the same number of hairs as Lila generally is not a reason for her to care about his fault. So given her relation to Robert, and her lack of any relationship to our Romans, it seems warranted for Lila to care more about Marcelle's fault than about Trajan's. Marcelle's fault concerns Lila more, or has more normative import or significance for her. Indeed, something even stronger seems true. If caring is a response to reasons, and if there is no good reason for her to care about Trajan's fault but plenty of reason to care about Marcelle's, it would in an important sense be unwarranted for Lila to care equally much about either. If she got worked up equally much, or little, about either fault, her caring would be at odds with her reasons to care, or with the grossly unequal significance that these faults have for her. She would ignore the import of her relations.

Now what kinds of reasons are these reasons to care? We might try to suggest that they are non-fittingness reasons. We might stick with the simple view about the representational content of the reactive attitudes (from section 1), on which the fittingness of a certain degree of indignation is determined fully by the de-

31 Here and in what follows, I say "putative(ly)" because whether you respond with a certain emotion ultimately depends on whether you take something to have a certain property, rather than on whether it actually has it. 
gree of the wrongdoer's fault. On this view, the uniquely fitting response for Lila would be equal indignation at Trajan and Marcelle. But we might suggest that Lila has non-fittingness reasons to (get herself to) care more about Marcelle's fault: prudential or moral reasons to be emotionally invested in her husband, say, but insouciant about our Romans. So it is somehow all-things-considered reasonable for her to (get herself to) feel unequal indignation at them. But this seems dubious. First, it seems to intuitively mischaracterize caring. There are nonrepresentational feelings for which there are only non-fittingness reasonslike hunger, tiredness, or pain. But, intuitively, the attitude of caring seems different. It seems propositional or representational. Something's being significant for you seems a reason for you to care in much the same way as something's being dangerous is a reason for you to be afraid. Second and more specifically, the suggestion seems to misdescribe Lila. Suppose someone offers her \$1,000 if, or tortures a cat unless, she feels resentment at her chair. Perhaps this gives her prudential or moral reasons to (get herself to) resent it: to misrepresent the facts, or emotionally pretend her furniture was blameworthy while knowing it is not. But intuitively our case is different. In responding more strongly to Marcelle's fault than to Trajan's, she does not seem to misrepresent anything, or involve herself in a contradiction between her emotions and her beliefs. In particular, Lila's emotions need not represent Marcelle as having evinced worse attitudes than Trajan, or as being more responsible for them. Lila may know that Marcelle and Trajan are equal in these respects, and intuitively her attitudes need not contradict this. Indeed, third, recall that Lila's emotions are entirely standard. So the proposal implies that all of us are constantly involved in blatant misrepresentations of people's faults, or contradictions among our representational mental states. Such widespread attribution of error seems hard to bear. If anything, it seems, Lila's emotions would misrepresent the facts if she got worked up as little about Marcelle's fault as about Trajan's, or as much about Trajan's as about Marcelle's. In doing so, she would falsely pretend that these faults concern her equally little, or much. She would misrepresent their unequal significance for her.

I do not see any convincing way of salvaging a non-fittingness interpretation of Lila's reasons to care. More plausibly, these reasons of significance are fittingness reasons. Something's being significant for you makes it fitting for you to care about it. That is to say, its significance is part of the representational content of your response toward it. So in the remainder of this paper, I will try to turn these first intuitions into a more full-fledged account of the fittingness of reactive emotions. Let us first clarify the idea of significance. It is not that something either is or is not significant for you. Take Trajan's betrayal of Hadrian. This betrayal may make a range of emotions fitting in virtue of instantiating a range of value prop- 
erties. Perhaps it proved the theory of some diligent twentieth-century historian, allowed her a publication, and got her a deserved career. If so, as something that was good for that historian, our betrayal may make it fitting to be glad. Perhaps it constituted an aesthetically compelling narrative, and as such may make it fitting to feel aesthetic appreciation. Perhaps it amazingly figured in a dream of a Peruvian farmer who knew nothing of ancient Rome, and as such may make it fitting to be amazed. And I assume it also makes it fitting to feel indignation or resentment. I will say it does so, specifically, as something for which Trajan is blameworthy. So our betrayal may be significant for you in different respects, or as an instantiation of different properties. For our diligent historian, the betrayal seems significant as something that was good for her. This property of the betrayal concerns her. But it does not seem significant for her as something for which Trajan is blameworthy. She does not have any personal relationship to our Romans. For Trajan's and Hadrian's friends, in contrast, our fact will be significant as something for which Trajan is blameworthy, but insignificant as something good for our historian. And for still other people, it might be significant in still other ways.

Here is how I will understand this more formally. By saying that some $x$ is (more/less) significant for you as an instantiation of a certain objective value property $F$, I mean that, due to your relationship to the fact that $x$ is $F$, it is fitting for you to be (more/less) affected by the emotions that $x$ 's being $F$ ultimately makes agent-neutrally fitting. If you are (more/less) so affected, due to your (putative) relationship to $x$ 's being $F$, I will say you care (more/less) about $x$ as an instantiation of $F$. Indeed, for you to care (more/less) about $x$ as an instantiation of $F$ just is for you to be (more/less) affected by the emotions that $x$ 's being $F$ ultimately makes agent-neutrally fitting due to your (putative) relationship to the fact that $x$ is F. Put simply, significance makes it fitting for us to care, and caring is our response to (putative) significance. ${ }^{32}$ But caring is not an extra emotion, alongside indignation, gladness, or admiration, say. It is a component of your feeling another emotion to a certain degree. And in this sense, the significance of $x$ as $F$ for you will be part of the representational content of your response to $x$ 's being $F$.

Let us spell this out for the reactive emotions. I will assume that what my

Note that, in this explication, $x$ might be anything - a fact, an event, an object, or whatever. By "objective value properties" I mean value properties that are not essentially relative to you (e.g., to your epistemic situation), perhaps like something's being disappointing or surprising. What I say could be extended to such essentially relative properties too. But for simplicity, I focus on objective ones. By the emotions that some fact "ultimately makes agent-neutrally fitting," I mean those it would make fitting for an impartial spectator, or regardless of its agent-relative significance. 
being blameworthy for a fault ultimately makes fitting are specifically (and only) the negative reactive attitudes. So that my fault is (more/less) significant for you as something for which I am blameworthy means that due to your relationship to the fact that I am blameworthy for it, it is fitting for you to be affected (more/ less) by the resentment or indignation my fault ultimately makes agent-neutrally fitting. And if you therefore feel (more/less) indignation at me, you care (more/ less) about my fault as something for which I am blameworthy. Indeed, for you to care (more/less) about my fault in this respect just is for you to feel (more/ less) indignation at me, in response to my fault's (putatively) being (more/less) significant for you as something for which I am blameworthy. Thus your overall degree of indignation among other things comprises your caring. In feeling a certain indignation at me, you represent me as thereby having manifested an attitude toward you that was morally wrong and for which I was responsible, and represent my fault as being significant for you. The stronger your resentment, the more seriously wrong you represent my attitude as having been, or the more fully responsible you represent me as having been for it, or the more significant you represent it as being for you. In this sense, the reactive attitudes, like other emotions, have an agent-relative element. They are not just a response to faults. They are a response to faults that are (putatively) significant for you.

This is the account I will develop in what follows. And this, I suggest, is why we can fittingly refrain from blaming people even if they are blameworthy. Lila's mild form of indignation at Trajan need not falsely represent him as not being equally blameworthy as Marcelle. It can correctly represent his fault as equally serious, but less significant for Lila than Marcelle's. To anticipate, I will suggest that Lila would forgive Jack for his promise breaking if she did not care about it anymore, as something for which he is blameworthy, and thus represented it as being sufficiently insignificant. But before I turn to forgiveness, let me elaborate more on this picture.

\section{THE REASONS OF SIGNIFICANCE}

I have indicated what kind of reasons may be relevant for overcoming resentment: fittingness reasons of significance, which you have in virtue of your relationship to someone's fault, as something for which they are blameworthy. The weaker your relationship to it, the weaker your reasons to care. But what relationship to something's instantiating a value property makes it significant for you as an instantiation of it? When do you have reasons to care about something?

This important question seems underexplored in the theory of emotions, and 
would be worth devoting an entire book to. ${ }^{33}$ But I suggest the answer has to do with what grounds the relevant property instantiation: $x$ is significant for you as an instantiation of $F$ to the extent that you are bound up with what grounds the fact that $x$ is $F$. Trajan's betrayal is significant for you as something that was bad for Hadrian to the extent that you are bound up with the grounds of this badness-e.g., involved with Hadrian's suffering. It is significant for you as something that was good for our historian to the extent that you are bound up with the grounds of this goodness-e.g., confronted with her joy or the benefits she reaps from her career. In a thorough general answer to our question, the phrase of your being "bound up" with something would have to be spelled out more. But I will assume we have a certain intuitive understanding of it, and for present purposes this will suffice. So rather than elaborating on this general criterion, let me say how I think it applies to blame.

Suppose a wrongdoer is blameworthy for wronging a victim. If I am right, his blameworthiness will be significant for you to the extent that you are bound up with what grounds it. So what will that be? There are different stories, but let us assume the picture of Strawson. ${ }^{34}$ On this picture, our blameworthiness is essentially grounded in our "involvement ... in inter-personal human relationships." 35 For Strawson, it is a constitutive feature of a normal interpersonal relationship that we demand of others a certain form of goodwill or regard toward us. ${ }^{36}$ The presence of this demand distinguishes such relationships from those we have toward children or psychopaths. And to make such a demand just is to respond with negative reactive attitudes to its violations. ${ }^{37}$ If this is roughly right, then what grounds our wrongdoer's blameworthiness is the fact that the victim is a source of demands on our attitudes, that the wrongdoer is a responsible person with whom we stand in relationships shaped by such demands, and that his attitude toward the victim violated a demand she is a source of.

So, for one thing, his blameworthiness will be more significant for you the more you are bound up with the importance of the pertinent demand. Most prominently, it will be more significant for you the more you are bound up with the victim, or with the fact that she is not just something that is fascinating for biochemistry, say, but a source of moral demands. When precisely you are so bound up with her depends on what about her grounds these demands. But plausibly,

33 Though for very interesting explorations, see, e.g., Helm, Emotional Reason; Kolodny, "Which Relationships Justify Partiality?"; and Lord, "Justifying Partiality."

34 Strawson, "Freedom and Resentment."

35 Strawson, "Freedom and Resentment," 9.

36 Strawson, "Freedom and Resentment," 15.

37 Strawson, "Freedom and Resentment," 23. 
you will be bound up with her in this manner if you are involved with the value of her leading the life she chooses, faring well, and being embedded as a member in equal standing in a moral community-if you have been confronted with this value and it matters or should matter to you. Other things equal, it is fitting for Lila to care more if someone got aggressive and broke her husband's nose than if that person got aggressive and broke the nose of a stranger. Indeed, other things equal, it would be unfitting for her to care more about the fault that affected a stranger than the fault that affected her husband. Her caring would be at odds with her reasons to care, or her involvement with the victims. She is more bound up with her husband as a source of demands than with a person she has never met.

For another thing, a wrongdoer's blameworthiness will be more significant for you the more you are bound up with the wrongdoer, or with the fact that he is not just an object of historical studies or social planning, but an object of moral demands, or a person in human relationships shaped by them. And this will be the case to the extent that you actually stand in such a relationship with him. When precisely you do, or to what extent, is a complex issue. Plausibly, you may have such a relationship even to people you do not literally interact with, as when you regard your favorite author or a stranger under the guise of a fellow person. But you are more fully involved with someone to the extent that you actually share your life or navigate a common space with them. Other things equal, it is fitting for Lila to care more about xenophobia in her mother than about the same xenophobia in a stranger, even if the relevant victims are the same. Indeed, it would be unfitting, or at odds with the import of these faults for her, if she cared more about the fault of a stranger than that of her mother. She is more bound up with her mother as an object of interpersonal demands.

But these are only roughly the main determinants of significance. There are a host of other factors beyond this. Most importantly, if your involvement with the wrongdoer matters, his response to his wrong matters too. At least insofar as you actually interact with him, you stand in a relationship with the present person, not with whom he once was. So the more he distances himself from his fault through remorse and a change for the better, the less it manifests a deficiency in a relationship in which you actually stand, or in a person whose being the object of demands you are bound up with. The more he separates himself from his wrongful attitudes, the less you are involved with his past demand violation, or with what grounded the fact that he was to blame. His past self will be a bit like a stranger. Other things equal, it is fitting for Lila to care more about her brother's wrongful outburst of rage if he has never felt remorse for it than if he has felt genuine guilt and has since tried hard and succeeded to be placid.

Moreover, it is not that you will simply have $a$ more or less close relationship 
to a wrongdoer. You have different relationships with different people, or relationships to specific aspects of them. So you are more fully bound up with the fact that a wrongdoer violated a demand the more that demand is important in the specific relationship you have to him. It might affect Lila that her neighbor Jack is endearingly cheerful in brief encounters, that he fully respects her privacy, and that he is generally very happy to do her a favor. But Jack's stubbornness in political matters, or his cowardice, or his characteristics as an employer, might be largely irrelevant to their relation. So while it is fitting for Lila to care more about Jack's political stubbornness than about that of a total stranger, other things equal, it is fitting for her to care even more about that stubbornness in Louisa, with whom she interacts in the local government. And that is so even if she does not have a closer relationship to Louisa than to Jack on the whole.

Similarly, it is not just your relationship to the victim that determines how much you are bound up with the relevant demand. There are other ways in which you might be bound up with it, or its grounds, or the grounds of why it is important. For instance, you are more involved with the importance of a demand if you have experienced how a violation of it can be harmful. You are more fully bound up with the demand to drive cautiously if as a result of someone's reckless driving you have once lost a child. The same may be true if you have dedicated your life to victims of road accidents. And something similar holds, all the more poignantly, if the present reckless driving had terrible consequences that you are involved with. Other things equal, it is fitting for Lila to care more if her friend Della drove recklessly and killed the child of Lila's neighbors than if she luckily did not harm anyone. ${ }^{38}$

All of this is rough, and plausibly not exhaustive. But it illustrates the general idea. The emerging overall picture is that our patterns of significance form a complex web. On the one hand, significance is infectious: if some things are significant for you in certain respects, then so are others that are appropriately connected to them. If the value of that house is significant for Lila, then so is Jack's promise breaking, which puts it at peril. On the other hand-and as will become important later on-significance must always be relative: if certain things are significant for you in certain respects, then others that are not connected to them will have to become less significant for you in comparison. If on the same evening there is a train crash that kills Lila's mother, Jack's promise breaking will suddenly be relatively insignificant next to it. The more specific upshot is that it is fitting for you to care about a wrongdoer's blameworthiness to the extent that

38 I think this grounds an important kind of moral luck, which I explore in Riedener, "Don't Make a Fetish of Faults." Scanlon makes a similar claim, within his different conception of "blame" (Moral Dimensions, 147-51.). 
you are bound up with the victim as a source of demands and the wrongdoer as a participant in human relationships-or specifically, to the extent that the wrong is still associable with the wrongdoer's attitudes, matters in your relationship to him, actually harmed you, and so on. These reasons are part of what reactive attitudes respond to, and of what they represent. Or so I claim.

\section{THE DISCRETION IN CARING}

I have suggested what kind of reasons our reasons of significance are. And I have made a proposal about when they arise. The significance of a value fact for you, we might say, is a quantity determined by how much you are bound up with its grounds, and determining how much caring is fitting in response to it. It remains to examine what the effect of these reasons will be. If significance is such a quantity, does that mean you must always care to one specific degree in order to have fitting attitudes? Or may you generally care to different degrees and still have fitting emotions?

At least in theory, there are two extreme views about how much discretion in fitting caring you have. One the one hand, one might think you have total such discretion. You can always care as much or as little as you please, without your caring ever being unfitting. On the other hand, one might think you have no such discretion at all. Given your relationship to a fault and to everything else, there is always just a single degree to which you can fittingly care. I have already suggested that the first view is intuitively implausible. Some forms of caring seem unfitting. Suppose Lila's close friend Della drove with outrageous recklessness, killed Lila's nephew, and hardly showed any remorse. And suppose someone named Edward drove with that very same recklessness a hundred years ago on the other side of the planet, but did not cause any harm, soon felt deep remorse, and drove with uttermost caution ever after. ${ }^{39}$ Other things equal, Lila cannot hold that the second incident concerns her more than the first. It just does not. And if she cared very much about Edward's but very little about Della's fault, her attitudes would misrepresent the significance of these faults for her. In caring about a fault, there is generally a minimal degree to which you must and a maximal degree to which you may care about it, in order for your caring to be fitting.

Why is this so? Well, it just follows from the fact that caring is a represen-

39 Recall that I regard the degree of your fault as being fully determined by the wrongness of, and your responsibility for, your attitude. Whether or not, unluckily or luckily, you end up harming someone with a given attitude does not determine the degree of your fault. It determines its significance. So as I understand the cases involving reckless driving in this section, the faults of the agents are the same. They only differ in significance for Lila. (On significance and moral luck, see also note 38 and the corresponding paragraph.) 
tational response to significance, in the manner I have suggested in section 3 . Suppose you could feel extreme "shfear" in response to a totally harmless mouse, and no shfear at all in response to a very dangerous snake, without this being an unfitting response to the dangerousness of these animals. Then shfear would not be a representational response to danger. It would be a nonrepresentational feeling like hunger, or perhaps a representational response to something altogether different. Similarly, suppose you could care very much about one fact that intuitively did not concern you at all, and very little about another fact that concerned you very much, and your caring would not be an unfitting response to the significance of these facts for you. Then caring would not be a representational response to significance. It would be a nonrepresentational feeling, or a representational response to something else. But it is a representational response to significance, or so I have argued.

However, to some extent at least you are free in how much you care. It is not always just one degree of caring that is fitting. Suppose Lila's acquaintance Grace once drove with a recklessness equal to Della's and Edward's. And say Lila has long had a good but rather impersonal relationship to Grace, that Grace's driving took place in distant Anchorage and damaged a fence post, and that she felt considerable but not quite the remorse she should have. These facts may determine some limits to Lila's caring. Other things equal, she can neither fittingly pretend that Grace's fault does not concern her at all (or less than Edward's), nor that it concerns her tremendously much (or more than Della's). But in between these extremes, she arguably has a large range of degrees of caring that are fitting. Within this range, she can fittingly care more or less. Not just one degree of caring seems fitting.

Why is this so? It helps to consider other cases, independent of significance, where we are justified to have attitudes of varying strength. Take aesthetic value. Consider a good artwork, such as Klee's little painting Dieser Stern lehrt beugen. And compare it to an absolute masterpiece like Tolstoy's War and Peace, and to an amateur work like a clay sculpture Lila once produced in adolescence. Other things equal, intuitively, you cannot fittingly admire Klee's small painting more than Tolstoy's novel, or less than Lila's sculpture. In doing so you would pretend it was more valuable than the former or less valuable than the latter, and that would be a misrepresentation. But compare Klee's painting to another artwork that is far from dilettantish but not quite epoch making either-such as one of Bartók's Romanian Folk Dances. Here, intuitively, you can fittingly feel the same degree of admiration toward them. But you can also fittingly feel somewhat 
more admiration at the painting than at the composition, and vice versa. None of these combinations of attitudes must be misrepresenting their worth. ${ }^{40}$

There might be different ways to explain this. But a standard and I think plausible way of doing so is in terms of incommensurability in values or reasons. That a certain form of value gives rise to incommensurability means that instances of it are not representable by a single value function, but only by a set of value functions. Your attitudes are fitting if and only if the values they represent things as having accord with one of the functions in the set. More intuitively, we might say, instances of the value are not representable as a single determinate quantity (precisely $k$ on some scale), but only as a range of values (somewhere between $n$ and $m$ ). And your attitudes are fitting if and only if the values they represent things as having fall within that range. ${ }^{41}$ Thus in order to have fitting attitudes, you must have some attitudes from this range, but may have any attitudes in it: you do not have conclusive (fittingness) reasons for one degree of emotion, but sufficient (fittingness) reasons for many. This can account for your discretion in response to art. Aesthetic value is not a precise determinate quantity. The value range of Klee's painting lies fully between the ranges of Lila's sculpture and Tolstoy's novel. So in order to have fitting attitudes, you must admire it more than the former but less than the latter. But since the value ranges of the works by Klee and Bartók overlap, you can fittingly feel equal admiration toward them, or somewhat more admiration for either. ${ }^{42}$

Why not think the works of Klee and Bartók are precisely equally valuable? Here is the standard "small improvement argument." Had Bartók chosen a slightly more mesmerizing melody, his piece would have been determinately (slightly) better than it is. But it would still not necessarily be determinately better than Klee's painting. So the actual composition cannot be precisely equally as valuable as the painting. For classic defenses of the pervasiveness of such incommensurability, see, e.g., Raz, The Morality of Freedom, ch. 13; and Broome, "Is Incommensurability Vagueness?" For a classic challenge, see Chang, "Introduction."

Strictly speaking, the set- and range-theoretic statements are not equivalent. Let $V$ be a set of value functions. It could be that on all individual functions in $V$, the value of $x$ is greater than that of $y$-i.e., that for all $v$ in $V, v(x)>v(y)$ —and yet that the ranges of values assigned to $x$ and $y$ by different functions in $V$ overlap-i.e., that for some $u$ and $w$ in $V$ and real number $k, u(x)=w(y)=k$. The set-theoretic formulation is more precise, or allows us to capture more fine-grained differences-and is thus standard in decision theory (see e.g., Dubra, Maccheroni and Ok, "Expected Utility Theory without the Completeness Axiom"; also Broome, "Is Incommensurability Vagueness?"). But since the range-theoretic statement is simpler, and the details do not matter for our purposes, I rely on that in what follows.

42 For an analysis of incommensurability in terms of permissible ranges of attitudes, see, e.g., Rabinowicz, "Value Relations Revisited," esp. 139n3; and Raz, "Incommensurability and Agency." There is a related discussion about reasons for action: Why are you generally justified to do various actions, rather than required to do any one? For an explanation of such discretion in action in terms of incommensurability, see, e.g., Raz, Engaging Reason. My picture 
Incommensurability in this sense is arguably pervasive. There is ample incommensurability in badness, tragedy, or awesomeness, say—or rarely just a single degree of sadness, dismay, or awe you can fittingly feel about instantiations of these properties. Very plausibly, there is similar incommensurability in significance. Significance is not a precise determinate quantity. It does not give you conclusive (fittingness) reasons for one degree of caring, but sufficient (fittingness) reasons for different degrees. Lila cannot fittingly pretend that the recklessness of her acquaintance Grace in Anchorage concerns her less than Edward's or more than Della's. But compare Grace's fault with an equal fault by a stranger in Lila's neighborhood. In many such cases the significance resulting from Lila's involvement with the wrongdoer will not be fully commensurable to that resulting from her involvement with the wronged. So Lila can fittingly care equally about these faults, or somewhat more about either of them. The incommensurability of significance gives her discretion in fitting caring.

Indeed, it arguably gives her quite a lot of it. For one thing, the relevant incommensurabilities will be ample. Incommensurability arises especially when a property has a number of diverse and hard-to-measure factors. Aesthetic value is determined by emotional depth, beauty, and immediacy, by the interplay of harmony and tension, and so on. These factors are diverse and hard to measure, and this grounds the wide incommensurabilities in art. ${ }^{43}$ Significance too is based on numerous factors, which are equally diverse and hard to measure. So here too incommensurabilities will be substantial. Moreover, they will multiply through their relations. Lila has a certain discretion with respect to how much she cares about Jack tout court, or about the demand for reliability as it applies to him, or the hours she has lost in fetching her saw. If she cares much, or little, about these background things, she may fittingly care correspondingly more or less about his fault. The incommensurabilities will grow with a ripple effect through the knots of the web of significance. And, indeed, if significance is always also relative as I have suggested, then the significance of Jack's promise breaking will also depend on how much she cares about the train crash of her mother, or about a recent earthquake in the Philippines and so on, even if those things are not intrinsically connected to it at all. So Lila will have a broad range of ways of caring about Jack's fault that are fitting.

is also reminiscent of Gert's account (see, e.g., "Requiring and Justifying”). Gert contrasts his account with the idea of incommensurability. But he also thinks the strength of reasons must be represented by value ranges, whose lower and upper bounds determine their "requiring" and "justifying" dimension respectively. The upshot of this is parallel to the picture I have sketched. For different accounts of our discretion in action, see, e.g., Greenspan, "Making Room for Options"; and Portmore, "Imperfect Reasons and Rational Options."

See, e.g., the standard arguments in Chang, "Introduction," 14-17. 
Hence the following picture suggests itself. In caring about Jack's fault to a certain degree, she does not represent it as giving her conclusive (fittingness) reasons for this and only this degree of caring. She represents it as giving her sufficient (fittingness) reason to care to that degree. And due to the incommensurability in significance, she might have sufficient reasons for different degrees. Given the history between Lila and Jack, his own response to his negligence, the extent to which she was actually harmed, and so on, as well as a context of other value facts, there will be forms of caring about his promise breaking that are unfittingly detached, and others that are unfittingly involved. But in between these extremes, there will be a range of different fitting responses. In light of Lila's complex relationship to Jack's promise breaking, she may fittingly care considerably about it, and fittingly care rather less - just as you may fittingly feel different degrees of admiration for Klee's little painting. ${ }^{44}$

\section{AN ACCOUNT OF FORGIVENESS}

This indicates a new account of forgiveness. Again, the stronger your resentment, the more serious you represent my fault as having been (in terms of wrongness and responsibility), or the more significant you represent it as being for you. And that you represent it as being very (or not so) significant for you means you represent it as being such that in virtue of your relationship to it, you have sufficient reasons to care greatly (or little) about it, as something for which I am blameworthy. That is how your blame registers more than my blameworthiness, and why you can fittingly refrain from blaming me even if I am blameworthy. And the overcoming of resentment in forgiveness revolves around this factor of significance.

44 In view of Allais's claim that "wrongdoing entitles us to resent, but this does not mean that it obliges us to" ("Elective Forgiveness," 647), it might be worth summarizing the senses in which, on the picture I have sketched, the fact that a certain emotion is fitting means you are "required" to feel it. There is a simple sense in which it does mean this. If the fact that $x$ is $F$ makes emotion $E$, and only $E$, fitting, then in order to have the (or a) fitting response to $x$ 's being $F$, you must feel $E$. If you do not, you lack a fitting response to that fact. However, there are three different senses in which for all I have said "fittingness" is not "requiring," but may be merely "permissive." First, there is the more fundamental question about whether there is, say, a moral or prudential requirement to have fitting attitudes in the first place. Perhaps there is not. Thus even if you have unfitting attitudes, perhaps you are not violating any such requirement. Second, there is the form of emotional oblivion mentioned above. If you lack any representation of $x$ 's being or not being $F$, you do not have unfitting emotions toward $x$ 's being $F$. Indeed it might be that all of your emotions are fitting. You just lack the fitting response, specifically, to $x$ 's being $F$. Third, if there is incommensurability, it might be that $x$ 's being $F$ makes both $E_{1}$ and (incompossible) $E_{2}$ fitting. Then you might lack $E_{1}$ and still have a fitting response to $x$ 's being $F$-viz., by having $E_{2}$. 
If Lila forgives Jack for his promise breaking, she does not care about it anymore, as something for which he is blameworthy. She comes to represent it as not being significant for her anymore, in this specific respect. She comes to represent Jack's fault a bit like that of a stranger, at least as his blameworthiness goes. Now this does not mean that Lila would eschew any response to Jack's fault, or no longer care about it tout court. There are other responses to Jack's promise breaking besides the negative reactive emotions. Lila may respond with sadness to the incident and henceforth feel a sense of sorrow in Jack's presence; she may respond with a desire to stay somewhat out of his way; or she may respond with curiosity and attempt to find out why Jack broke his promise. But these responses would not ultimately be made fitting by Jack's being blameworthy for his fault. They would ultimately be made fitting, say, by the fact that Jack's promise breaking was bad for Lila (e.g., if the oak fell on her house), or by the fact that it is evidence for the undesirability of future involvements, or by the fact that it promises interesting insights (e.g., about how to prevent promises being broken in the future). Again, I take it that what our being blameworthy for a fault ultimately makes fitting are specifically and only the negative reactive attitudes. So if Lila had these other responses, she would care about Jack's fault in these other respects - as something that was bad, or evidence for the undesirability of involvement, or intellectually interesting. And all of these responses would be compatible with her having forgiven. In forgiving, she just comes to no longer care about the promise breaking specifically as something for which Jack is blameworthy. In this sense, she overcomes her resentment, due to its (putative) lack of significance for her in this specific respect.

If all I have said is correct, this solves the problem from section 1. In no longer feeling resentment, Lila would come to represent Jack's fault as being such that in virtue of her relationship to it she has sufficient reasons not to care about it anymore. And at least in some circumstances-perhaps if nothing much happened and Jack felt some remorse-this may certainly be true. So she may fittingly not feel resentment. In still feeling resentment, Lila would represent Jack's fault as being such that she has sufficient reasons to still care about it. And this may also be true, even in the very same circumstances. Since significance is not a precise determinate quantity, but involves incommensurabilities, these circumstances will give her sufficient reasons for several degrees of caring. So even when she may fittingly not feel resentment, she may also fittingly still feel it. And note that if she does care less, she does not just lack any representational response to Jack's fault. To represent it as insignificant is not to not represent it at all. So in no longer caring she would not just end up with emotions that are not unfitting. She may end up in a positively fitting emotional state. There is 
no real "paradoxy" in forgiveness. Our discretion in fitting forgiveness is part of our more general discretion in how much we care about things. ${ }^{45}$ As emphasized, that latter discretion has limits. But then our discretion in forgiveness has limits too. Sometimes - with remorseful wrongdoers whose wrong is long past and has not harmed us at all—resentment is no longer fitting. And sometimeswith unapologetic close wrongdoers who have just harmed us severely-resentment just is the fitting response. So I take it the proposal gets the measure of our discretion quite right.

However, no longer caring about a wrong as something for which the wrongdoer is blameworthy plausibly is not sufficient for forgiveness. If Lila sought peace of mind, took a tranquillizer pill, and eventually no longer blamed Jack due to the chemistry of this pill, she has not forgiven. Neither has she done so if she does not care about his wrong only because her mother died and this rendered her indifferent about that promise. Nor is it forgiveness if out of contempt she no longer cared about Jack tout court. So we need to say more. Nothing of what I have said so far depends on how we explain why these ways of ceasing to care are not forgiveness. But let me add a proposal. Lila's lack of resentment must be reason responsive (not just the effect of some pill), and the relevant reasons must have their source at least partly in Jack (not just in some unrelated event) and in something that is lovable about him (not in what perhaps makes fitting contempt). ${ }^{46}$ So I suggest that Lila forgives Jack for his promise breaking if and only if she no longer cares about it partly out of goodwill toward him. Or more precisely: Lila forgives Jack for his promise breaking if and only if, while believing that he was at fault for it, and partly out of goodwill toward him, she no longer cares about his promise breaking as something for which he is blameworthy. To forgive just is to no longer care in this manner.

What do I mean by this? As I will understand it, you $\phi$ out of an attitude if your having that attitude plays an unmediated causal role in why you $\phi$. And it is in this sense that Lila might not care about Jack's fault "out of goodwill" toward him. Her not caring might partly be the unmediated consequence of her having a positive attitude toward him. The phrase "unmediated" here is intended to rule out cases where Lila's goodwill indirectly causes her not to care. If out of goodwill

45 One might think that Lila's relationship to the victim will not be relevant for forgiveness. After all, she is the victim, and (one might think) will have a fixed relationship to herself. But note that what matters is her relationship to the victim as a source of demands. And she can be more or less bound up with herself in this respect. For instance, if she is struggling for a sense of self-worth, she will experience the importance of others' respect toward her firsthand. In this case, she may be more bound up with herself as a source of the demand for respect than if she has a fully firm sense of her worth.

This is emphasized especially in Milam, "Reasons to Forgive." 
Lila intends to benefit Jack, and takes a pill that causes her not to care about his fault, she has not properly forgiven. In the sense I intend, she did not cease caring "out of goodwill," but due to the effect of that pill. More positively, in a case of fitting forgiveness, there is some property of Jack that makes it fitting for Lila to feel goodwill toward him. Lila feels goodwill in response to that. But that property of Jack also makes his fault less significant for Lila as something for which he is blameworthy. So in coming to appreciate that property, Lila also comes to see his fault as less significant for her. And it is partly due to this that she ultimately does not care about it anymore as something for which he is blameworthy.

Let me illustrate this with examples. The property of Jack that makes Lila's goodwill fitting might be something that renders his promise breaking intrinsically less significant for her. Suppose Jack repented his fault. This means Lila is less bound up with the grounds of his being blameworthy for it. So on the account from section 4 , it makes it fitting for her to care less about it. But it arguably also makes it fitting for her to feel goodwill toward him. If Lila comes to appreciate his remorse, responding with goodwill toward it, and therefore (among else) no longer cares about his promise breaking, she forgives him. But I think the relevant property of Jack might also be something that renders his promise breaking only relatively less significant for Lila-i.e., makes other things more significant, and thus Jack's fault less significant in comparison. Suppose Jack beams with a disarmingly endearing cheerfulness, an adorable childlike gaiety, and despite all his weaknesses it is a precious delight to have him around. Or suppose he is diagnosed with a terrible disease, and undeservedly soon faces death. These facts have nothing to do with the grounds of his blameworthiness for that promise breaking. So they do not render it intrinsically less significant for Lila. But they make it less significant in the overall scheme of things, and specifically in her dealings with him. And they arguably also make it fitting for her to wish him well. If Lila comes to appreciate these aspects of Jack, responding with goodwill to them - with a love for her scatterbrained yet congenially joyful or pitiably unlucky neighbor-and therefore (among else) no longer cares about his promise breaking in the pertinent manner, she arguably also forgives him. ${ }^{47}$ But I say it must be partly out of goodwill that Lila no longer cares. There may be other facts that render his fault less significant, and do not warrant any

Intuitions about whether such cases amount to "forgiveness" will be more disputed: Milam ("Reasons to Forgive"), say, would presumably deny it. I think they do. But my account could be modified to imply that they do not. We might require that the relevant property of Jack must render his fault intrinsically (not just relatively) less significant for Lila. Note also that as I understand the phrase "out of goodwill," it in effect implies a right-kind-of-reason requirement for forgiveness: in forgiving, Lila does not care due to something that (putatively) renders Jack's fault less significant, or is a fittingness reason not to care. 
such goodwill. Perhaps Lila's mother died on that evening, and this made our incident unimportant in comparison. Or perhaps Lila moved away, and is simply no longer involved with her former neighbor. These facts do not warrant goodwill toward Jack. So if it is only due to them that Lila no longer cares about his fault, she has not properly forgiven. But these facts do make his promise breaking less significant for her. So they can contribute to making it fitting for her not to care anymore, and help her actually not care. And as long as it is partly due to such facts that she does not care, and partly also out of goodwill-partly also in response to his remorse, say-they can contribute to making forgiveness fitting, and help her actually forgive. The threshold about when enough goodwill is involved will be vague. But this just mirrors that the concept of forgiveness is vague - and that there is a certain continuity between forgiveness and phenomena like oblivion or distraction. ${ }^{48}$

So if all of this is correct, then pace Allais, not all ways of ceasing to hold the promise breaking against Jack amount to forgiveness. Forgiveness is a narrower phenomenon than that. It must in part be a genuine response to a (putative) fact about Jack. Also, Lila's discretion in fitting forgiveness does not hinge on her epistemic limitations. It is fully grounded in the facts, or in the actual incommensurabilities of significance. And finally, blame and forgiveness are not all about assessing our characters. Of course it matters whether Jack's promise breaking is (still) characteristic of him. If it is not, this renders his fault less significant for Lila, and may thus allow her to fittingly not feel resentment in response to it. Indeed, it also makes it fitting for her to feel goodwill toward him, and thus may allow her to fittingly forgive - or not blame him partly out of such goodwill. But the significance of Jack's fault for Lila hinges on many other factors too, which do not depend on whether his unreliability is (still) characteristic. It depends on how close a relationship she (now) has to him, on precisely what kind of relationship they have, and on what role the demand for reliability plays in it. It depends on what ramifications it had, for Lila's afternoon or her house or her sense of self-worth. And it also depends on other facts in the context, about Jack, but also

Note that I think it is sufficient for forgiveness if it is partly out of goodwill that Lila now does not care about Jack's fault. It need not have been partly out of goodwill that she originally ceased caring. Suppose she originally ceased caring about it out of contemptuous disregard. But she later overcomes that disregard, and would come to care about Jack's fault and resent him again, were it not for the goodwill she now feels toward him in response to his sincere apology. In an important sense, I think, Lila then forgives him. Thus the process of "overcoming" resentment that constitutes forgiveness need not end once Lila lacks any resentment. It ends once she lacks it for the right reasons-i.e., once she does not care partly out of goodwill. (To that extent I am convinced by the arguments in Schönherr, "When Forgiveness Comes Easy.") 
about Lila's mother or even the Philippines. If these factors play out right, they too can make Jack's fault less significant for Lila, or allow her to fittingly not feel resentment in response to it. And some of them-such as his general cheerfulness or undeserved bad health - may also make it fitting to feel goodwill toward him, and thus allow her to fittingly forgive. So sometimes, Lila may fittingly forgive even if the promise breaking is expressive of Jack's character. And sometimes she may still fittingly resent him even though it is not. Being sensitive to all facets of significance, blame and forgiveness are complex responses indeed. ${ }^{49}$

\section{CONCLUSION}

Let me wrap up. I have introduced a version of the standard account of forgiveness. I have explicated a notion of the significance of value facts, provided an account of when such facts are significant for us in terms of their grounds, and outlined what this normatively implies. And I have argued that an account of forgiveness based on this phenomenon dissolves the apparent paradoxy and satisfies a number of desiderata. The account is also intuitively plausible. If Lila is a forgiving person, she will know that people go wrong. But she will be disposed not to dwell on their faults more than necessary, to distance herself from them- $\mathrm{a}$ bit as if they had happened far off. She will care about the good in people. If Lila is an unforgiving person, she may know that people do admirable things, and may not see their faults as worse. But she will be disposed to dwell on these faults if she may.

Naturally, there are many open questions. Most importantly perhaps, I have raised a number of general issues - about the representational content of emotions, the grounds and shape of their agent-relativity, or the extent to and reasons for which we are required to feel them. Some of these topics seem underexplored. It would be important to elaborate more on them. Being a version of the

49 It might also help to compare the present account to Hieronymi, "Articulating an Uncompromising Forgiveness." Hieronymi thinks your resentment is warranted in response to an action that wronged you, for which the agent was responsible, and that still makes a threatening claim to the effect that you may be treated thus. The wrongdoer's apology will undo that claim, and thus make your resentment lose its "point" (548), or become inappropriate. To forgive, she suggests, is to retract your resentment in response to that. Hieronymi does not say so. But perhaps one may interpret that threatening claim as making the fault significant for you. If so, then besides explicitly understanding the relevant issue as the general category of significance, there are again three main ways in which the present proposal goes beyond hers. Most importantly, it accounts for the complexity of forgiveness (and especially for forgiving the unapologetic) by allowing that a fault's significance depends on much more than its posing a threat. Partly in virtue of this, it can (and does explicitly) account for our discretion in forgiving. And at the same time, it elucidates why not all ways of overcoming resentment (even in response to apology) must amount to forgiveness. 
standard account, the proposal also raises familiar questions about forgiveness. Forgiveness is something that usually has normative effects-e.g., concerning the wrongdoer's duty toward the victim to repent. ${ }^{50}$ It is something that some people (notably the victim) seem in a privileged position to offer. ${ }^{51}$ And it is something we sometimes do with a goal. ${ }^{52}$ An account of forgiveness must explain these facts. I am confident that the present proposal has the resources to do so. But these are matters for another paper.

It would also be interesting to explore further dimensions of significance. For instance, presumably the significance of a value fact matters not just for attitudes, but also for action. We have stronger reason to act in response to a value fact the more significant it is. ${ }^{53}$ Also, presumably our freedom not to care extends to other emotions and beyond people's faults, onto facts of life more generally-pains and losses and defeats. Thus there will be ways of "forgiving life." Some people get habitually worked up about the foul and ugly and deplorable things, and stand aloof from what is worthy of gratitude or joy. And some people are just the opposite. And the difference seems important. In some instances, and as with forgiveness proper, a heightened concern with the good might amount to a dubious blindness to reality. But then again, if done in the right manner, it might also constitute an innocuous form of positivity and a reliable path to contentment. ${ }^{54}$

\section{University of Zurich stefan.riedener@philos.uzh.ch}

50 See, e.g., Warmke, "The Normative Significance of Forgiveness"; or Bennett, "The Alteration Thesis."

51 See, e.g., Murphy and Hampton, Forgiveness and Mercy, 32; Walker, "Third Parties and the Social Scaffolding of Forgiveness"; also Pettigrove, "The Standing to Forgive”; and Radzik, "Moral Bystanders and the Virtue of Forgiveness."

52 See, e.g., Hieronymi, "Articulating an Uncompromising Forgiveness"; and Fricker, "Forgiveness."

53 There is a straightforward link between attitudes and action if we regard your motivation to act in accordance with the reasons (for action) provided by a value fact as a fitting attitude toward it. Then the more significant a value fact is for you the more motivation to act on these reasons it is fitting for you to have. That the suffering of a friend is more significant for you than that of a stranger, as something bad, say, does not just mean it is fitting for you to respond with more sorrow. It also means it is fitting for you to be more motivated to help them. This might explain many of our intuitions of partiality.

54 I thank Barbara Bleisch, Susanne Boshammer, Samuel Hughes, Felix Koch, Benjamin Lange, Adam Lovett, Lukas Naegeli, Claire Plassard, Peter Schaber, Philipp Reichling, Felix Timmermann, R. Jay Wallace, two anonymous reviewers and an editor from the Journal of Ethics and Social Philosophy, and audiences in Zurich, Berne, Cologne, and Osnabrück for very helpful comments on earlier versions of this paper. 
Allais, Lucy. "Elective Forgiveness." International Journal of Philosophical Studies 21, no. 5 (2013): 637-53.

- "Wiping the Slate Clean: The Heart of Forgiveness." Philosophy and Public Affairs 36, no. 1 (Winter 2008): 33-68.

Anderson, Pamela Sue. "When Justice and Forgiveness Come Apart: A Feminist Perspective on Restorative Justice and Intimate Violence." Oxford Journal of Law and Religion 5, no. 1 (February 2016): 113-34.

Bennett, Christopher. "The Alteration Thesis: Forgiveness as a Normative Power." Philosophy and Public Affairs 46, no. 2 (Spring 2018): 207-33.

Blustein, Jeffrey M. Forgiveness and Remembrance: Remembering Wrongdoing in Personal and Public Life. Oxford: Oxford University Press, 2014.

Broome, John. "Is Incommensurability Vagueness?” In Chang, Incommensurability, Incomparability and Practical Reason, 67-89.

Butler, Joseph. Fifteen Sermons Preached at the Rolls Chapel. London: J. and J. Knapton, 1726.

Calhoun, Cheshire. “Changing One’s Heart.” Ethics 103, no. 1 (October 1992): 76-96.

Callard, Agnes. "The Reason to Be Angry Forever." In The Moral Psychology of Anger, edited by Myisha Cherry and Owen Flanagan, 123-38. London: Rowman and Littlefield, 2017.

Chang, Ruth, ed. Incommensurability, Incomparability and Practical Reason. Cambridge, MA: Harvard University Press, 1997.

_. "Introduction." In Chang, Incommensurability, Incomparability and Practical Reason, 1-34.

Couto, Alexandra. "Reactive Attitudes, Forgiveness, and the Second-Person Standpoint." Ethical Theory and Moral Practice 19, no. 5 (November 2016): 1309-23.

D’Arms, Justin, and Daniel Jacobson. "The Moralistic Fallacy: On the 'Appropriateness' of Emotions." Philosophy and Phenomenological Research 61, no. 1 (July 2000): 65-90.

Darwall, Stephen. The Second-Person Standpoint: Morality, Respect, and Accountability. Cambridge, MA: Harvard University Press, 2006.

Deonna, Julien A., and Fabrice Teroni. "Emotions as Attitudes." Dialectica 69, no. 3 (September 2015): 293-311.

Dubra, Juan, Fabio Maccheroni, and Efe A. Ok. "Expected Utility Theory without the Completeness Axiom." Journal of Economic Theory 115, no. 1 (March 2004): 118-33. 
Fricker, Miranda. "Forgiveness: An Ordered Pluralism." Australasian Philosophical Review 3, no. 3 (2019): 241-6o.

_- "What's the Point of Blame? A Paradigm Based Explanation." Noûs 50, no. 1 (March 2016): 165-83.

Garrard, Eve, and David McNaughton. "In Defence of Unconditional Forgiveness." Proceedings of the Aristotelian Society 103, no. 1 (2003): 39-60.

Gert, Joshua. "Requiring and Justifying: Two Dimensions of Normative Strength." Erkenntnis 59, no. 1 (July 2003): 5-36.

Gertken, Jan, and Benjamin Kiesewetter. "The Right and the Wrong Kind of Reasons.” Philosophy Compass 12, no. 5 (May 2017): e12412.

Goldie, Peter. The Emotions: A Philosophical Exploration. London: Oxford University Press, 2000.

Greenspan, Patricia. "Making Room for Options: Moral Reasons, Imperfect Duties, and Choice." Social Philosophy and Policy 27, no. 2 (July 2010): 181-205.

Griswold, Charles L. Forgiveness. Cambridge: Cambridge University Press, 2007 Helm, Bennett W. Emotional Reason: Deliberation, Motivation, and the Nature of Value. Cambridge: Cambridge University Press, 2009.

Hieronymi, Pamela. "Articulating an Uncompromising Forgiveness." Philosophy and Phenomenological Research 62, no. 3 (May 2001): 529-55.

Holmgren, Margaret R. "Forgiveness and the Intrinsic Value of Persons." American Philosophical Quarterly 30, no. 4 (October 1993): 341-52.

Howard, Christopher. "Fittingness." Philosophy Compass 13, no. 11 (November 2018): e12542.

Hughes, Paul M. “What Is Involved in Forgiving?” Journal of Value Inquiry 27, no. 3 (December 1993): 331-40.

Hurka, Thomas. Virtue, Vice, and Value. New York: Oxford University Press, 2001.

Hutto, Daniel D. “Truly Enactive Emotion." Emotion Review 4, no. 2 (April 2012): 176-81.

Kelly, Thomas. "The Rationality of Belief and Some Other Propositional Attitudes." Philosophical Studies 110, no. 2 (August 2002): 163-96.

Kolnai, Aurel. "Forgiveness." Proceedings of the Aristotelian Society 74, no. 1 (June 1974): 91-106.

Kolodny, Niko. "Which Relationships Justify Partiality? The Case of Parents and Children." Philosophy and Public Affairs 38, no. 1 (Winter 2010): 37-75.

Lord, Errol. "Justifying Partiality." Ethical Theory and Moral Practice 19, no. 3 (June 2016): 569-90.

Maguire, Barry. “There Are No Reasons for Affective Attitudes." Mind 127, no. 507 (July 2018): 779-805. 
Milam, Per-Erik. "Against Elective Forgiveness." Ethical Theory and Moral Practice 21, no. 3 (June 2018): 569-84.

—. "Reasons to Forgive." Analysis 79, no. 2 (April 2019): 242-51.

Murphy, Jeffrie, and Jean Hampton. Forgiveness and Mercy. Cambridge: Cambridge University Press, 1988.

Na'aman, Oded. "The Fitting Resolution of Anger." Philosophical Studies 177, no. 8 (August 2020): 2417-30.

Neblett, William R. "Forgiveness and Ideals." Mind 83, no. 330 (April 1974): 269-75.

Novitz, David. "Forgiveness and Self-Respect." Philosophy and Phenomenological Research 58, no. 2 (June 1998): 299-315.

Nussbaum, Martha C. Upheavals of Thought: The Intelligence of Emotions. Cambridge: Cambridge University Press, 2001.

Parfit, Derek. On What Matters. Vol. 1. Oxford: Oxford University Press, 2011. Pettigrove, Glen. Forgiveness and Love. Oxford: Oxford University Press, 2012.

- "The Standing to Forgive." The Monist 92, no. 4 (October 2009): 583603.

Portmore, Douglas W. "Imperfect Reasons and Rational Options." Noûs 46, no. 1 (March 2012): 24-60.

Prinz, Jesse. Gut Reactions: A Perceptual Theory of Emotion. Oxford: Oxford University Press, 2006.

Rabinowicz, Wlodek. "Value Relations Revisited." Economics and Philosophy 28, no. 2 (July 2012): 133-64.

Rabinowicz, Wlodek, and Toni Rønnow-Rasmussen. "The Strike of the Demon: On Fitting Pro-Attitudes and Value." Ethics 114, no. 3 (April 2004): 391-423.

Radzik, Linda. "Moral Bystanders and the Virtue of Forgiveness." In Forgiveness in Perspective, edited by Christopher R. Allers and Marieke Smit, 69-88. New York: Rodopi, 2010.

Raz, Joseph. Engaging Reason. New York: Oxford University Press, 1999.

- . "Incommensurability and Agency." In Chang, Incommensurability, Incomparability and Practical Reason, 110-28.

. The Morality of Freedom. Oxford: Clarendon, 1986.

Richards, Norvin. "Forgiveness." Ethics 99, no. 1 (October 1988): 77-97.

Riedener, Stefan. "Don't Make a Fetish of Faults: A Vindication of Moral Luck." Philosophical Studies 178, no. 3 (March 2021): 693-711.

Rosen, Gideon. "The Alethic Conception of Moral Responsibility." In The Nature of Moral Responsibility: New Essays, edited by Randolph Clarke, Michael McKenna, and Angela M. Smith, 65-88. Oxford: Oxford University Press, 2015. 
Scanlon, T.M. Moral Dimensions: Permissibility, Meaning, Blame. Cambridge, MA: Harvard University Press, 2008.

Schönherr, Julius. "When Forgiveness Comes Easy." Journal of Value Inquiry 53, no. 4 (December 2019): 513-28.

Sharadin, Nathaniel. "Reasons Wrong and Right." Pacific Philosophical Quarterly 97, no. 3 (September 2016): 371-99.

Smith, Angela M. "Moral Blame and Moral Protest." In Blame: Its Nature and Norms, edited by D. Justin Coates and Neal A. Tognazzini, 27-48. New York: Oxford University Press, 2013.

Solomon, Robert C. "Emotions and Choice." Review of Metaphysics 27, no. 1 (September 1973): 20-41.

Strawson, P. F. "Freedom and Resentment." 1962. In Freedom and Resentment and Other Essays, 1-28. Abingdon, Uk: Routledge, 2008.

Tappolet, Christine. Emotions, Values, and Agency. Oxford: Oxford University Press, 2016.

—. "Values and Emotions: Neo-Sentimentalism's Prospects." In Morality and the Emotions, edited by Carla Bagnoli, 117-34. Oxford: Oxford University Press, 2011.

Walker, Margaret Urban. "Third Parties and the Social Scaffolding of Forgiveness." Journal of Religious Ethics 41, no. 3 (September 2013): 495-512.

Ware, Owen. "Forgiveness and Respect for Persons." American Philosophical Quarterly 51, no.3 (July 2014): 247-59.

Warmke, Brandon. "The Normative Significance of Forgiveness." Australasian Journal of Philosophy 94, no. 4 (2016): 687-703.

Watson, Gary. "Standing in Judgment." In Blame: Its Nature and Norms, edited by D. Justin Coates and Neal A. Tognazzini, 282-301. New York: Oxford University Press, 2013.

Way, Jonathan. "Transmission and the Wrong Kind of Reason." Ethics 122, no. 3 (April 2012): 489-515.

Zaibert, Leo. "The Paradox of Forgiveness." Journal of Moral Philosophy 6, no. 3 (January 2009): 365-93. 